\title{
Pengaruh Model Pembelajaran Berbasis Masalah terhadap Motivasi Belajar dan Hasil Belajar PPKn
}

\author{
Moh. Wahyu Kurniawan dan Wuri Wuryandani \\ Mahasiswa PPS Universitas Negeri Yogyakarta \\ PPS Universitas Negeri Yogyakarta \\ wahyuiwan41@yahoo.co.id
}

\begin{abstract}
The aims of this study were to analyze: (1) the significance effects of the Problem-Based Learning (PBL) Method on the motivation to learn PPKn, (2) the significance effects of PBL Method on PPKn learning result, (3) the significance effects of PBL on the result and motivation of the students in PPKn learning process, and (4) to find out the effectiveness among PBL Method, the Inquiry and Conventional Learning Method in learning PPKn. This research was quasi experiment by pretest-posttest control group design. The participants were the $10^{\text {th }}$ grade of SMA Negeri 1 Pacet Mojokerto 2016/2017 year academic. The results: (1) there were significance effects of the PBL Method on the motivation to learn PPKn; (2) there were significance effects of PBL Method on PPKn learning result; (3) there were significance effects of Problem-Based Learning on the result and motivation to the students in PPKn learning process; (4) the most effective method of learning PPKn was Problem-Based Learning.
\end{abstract}

Keywords: Problem-Based Learning Method, Motivation of Learning, and Learning Result.

\section{Pendahuluan}

Pendidikan merupakan sarana terpenting untuk mewujudkan kemajuan bangsa dan negara, hal ini karena pendidikan merupakan proses budaya yang bertujuan untuk meningkatkan harkat dan martabat manusia. Dalam Undang-undang Republik Indonesia No. 20 Tahun 2003 tentang Sistem Pendidikan Nasional Bab I Pasal 1 dinyatakan bahwa Pendidikan merupakan usaha sadar dan terencana untuk mewujudkan suasana belajar dan proses pembelajaran agar peserta didik secara aktif mengembangkan potensi dirinya untuk memiliki kekuatan spiritual keagamaan, pengendalian diri, kepribadian, kecerdasan, akhlak mulia, serta keterampilan yang diperlukan dirinya, masyarakat, bangsa, dan Negara. Artinya, pendidikan di sekolah merupakan proses yang terencana dan mempunyai tujuan, sehingga segala sesuatu yang dilakukan oleh guru dan peserta didik dapat mencapai tujuan pembelajaran. Melalui proses pendidikan terencana diarahkan untuk mewujudkan suasana belajar yang kondusif serta proses belajar yang menyenangkan, dengan tujuan peserta didik dapat mengembangkan potensi diri.

Melihat tujuan dari pendidikan nasional tersebut, maka efektivitas pembelajaran harus ditingkatkan, karena proses pembelajaran memegang peran penting dalam menghasilkan atau menciptakan lulusan yang berkualitas. Oleh karena itu, perlu mendapatkan perhatian yang lebih serius dari stakeholders untuk menciptakan kegiatan proses pembelajaran yang menyenangkan dan efektif. Salah satu usaha yang dapat dilakukan adalah pembaruan model pembelajaran yang dapat menyentuh kemampuan peserta didik dalam aspek kognitif, afektif maupun psikomotorik. Misalnya, model pembelajaran yang membiasakan peserta didik untuk aktif, sehingga peserta didik dapat mengembangkan seluruh kemampuan untuk bisa belajar secara mandiri dengan melihat isu-isu yang konvensional dalam kehidupan sehari-hari. 
Penggunaan model pembelajaran Pendidikan Pancasila dan Kewarganegaraan (PPKn) yang tidak tepat dapat berdampak pada kegiatan pembelajaran yang cepat membosankan, sehingga materi yang disampaikan sulit diterima oleh peserta didik, dalam hal ini akan berdampak pada hasil belajar dan motivasi belajar peserta didik rendah. Misalnya, peserta didik menjadi malas untuk berhadapan dengan mata pelajaran PPKn, seperti yang dikemukakan oleh Salani \& Maphane (2014, p. 217) bahwa "motivation is a process whereby goal directed behavior is instigated and sustained. In an organizational setup it is viewed as the willingness of employees to achieve organizational set goals".

Berdasarkan hasil observasi di SMA Negeri 1 Pacet menunjukkan sistem pembelajaran masih didominasi oleh sebuah paradigma yang menyatakan bahwa sebuah pengetahuan (knowledge) merupakan perangkat fakta-fakta yang harus dihafal. Di samping itu, situasi kelas sebagian besar masih berfokus pada guru (teacher) atau sebagai sumber utama pengetahuan, serta penggunaan metode ceramah sebagai pilihan dalam kegiatan pembelajaran di kelas. Temuan lain menunjukkan hasil ujian tengah semester (UTS) Tahun Pelajaran 2015/2016 pada mata pelajaran PPKn terdapat 47 peserta didik atau $59 \%$ dari 125 jumlah peserta didik pada kelas $\mathrm{X}$ mendapatkan nilai di bawah ketuntasan minimal yaitu 75. Standar keberhasilan belajar minimal yang ditargetkan oleh sekolah adalah sebesar $75 \%$. Hal ini membuktikan bahwa hasil belajar PPKn belum optimal.

Permasalahan-permasalahan yang terjadi dalam kegiatan pembelajaran ialah terdapat pada penggunaan model pembelajaran yang digunakan oleh pendidik kurang efektif dan kurang menumbuhkan pembelajaran yang demokratis, sehingga dibutuhkan inovasi dalam pembelajaran dengan menerapkan model pembelajaran yang dapat menumbuhkan motivasi belajar dan peserta didik mendapatkan hasil belajar yang maksimal khususnya dalam mata pelajaran PPKn. Upaya yang dapat memperbaiki suasana belajar yang efektif, sehingga lebih melibatkan peserta didik dalam kegiatan pembelajaran berlangsung yaitu melalui model pembelajaran berbasis masalah. Tujuannya ialah agar dapat meningkatkan keterampilan peserta didik untuk bekerja sama, menumbuhkan keterampilan berpikir kritis, dan mampu memecahkan masalah-masalah dalam kehidupan sehari-hari, khususnya dalam pembelajaran PPKn.

Pendidikan Pancasila dan Kewarganegaraan (PPKn) mempunyai peran yang sangat penting sebagai wahana untuk mengembangkan kemampuan atau potensi peserta didik untuk berfikir kritis menanggapi isu-isu atau permasalahan yang ada. Oleh karena itu, untuk mendorong kemampuan yang telah dimiliki oleh peserta didik, maka diperlukan penerapan model pembelajaran yang menghasilkan karya berbasis masalah untuk membangkitkan motivasi belajar dan hasil belajar peserta didik melalui pemecahan masalah yang terjadi di kehidupan sehari-hari. Model pembelajaran berbasis masalah merupakan suatu pendekatan pembelajaran yang menggunakan masalah dalam kehidupan sehari-hari sebagai suatu konteks bagi peserta didik untuk belajar tentang cara berpikir kritis, keterampilan pemecahan masalah, dan untuk memperoleh pengetahuan serta konsep dari materi pelajaran yang disampaikan. Menurut Etherington (2011, p. 53), bahwa pembelajaran berbasis masalah memandu peserta didik untuk menggali fakta-fakta yang berguna atau konsep yang telah ditemukan". 
Pembelajaran berbasis masalah membantu menumbuhkan peserta didik dalam memecahkan masalah melalui kerja sama dengan masyarakat setempat sebagai inovator. Model pembelajaran berbasis masalah merupakan salah satu bentuk pembelajaran yang berlandaskan pada paradigma constructivism yang sangat mengedepankan peserta didik dalam belajar dan berorientasi pada proses kegiatan pembelajaran. Permasalahan menjadi fokus, sementara guru menjadi pembimbing dan fasilitator untuk dapat memecahkan masalah, sementara peserta didik mencari informasi, memperkaya wawasan dari berbagai sumber dan keterampilan untuk berupaya aktif dalam belajar mandiri.

Pendapat lain dikemukakan oleh Schettino (2016, p. 8), bahwa melalui pembelajaran berbasis masalah di dalam kelas adalah tempat di mana merangsang kemampuan berkomunikasi, keterampilan metakognitif, keterampilan belajar seumur hidup, dan pengetahuan konten dipraktikkan dengan berfokus pada masalah. Pembelajaran kolaboratif merupakan elemen utama dari pembelajaran berbasis masalah (PBL), dengan menuntut peserta didik dapat memberikan kontribusi saat berdiskusi kelompok. Harapan ini timbul dari berbagai kerangka kerja konseptual yang menetapkan bahwa pembelajaran kolaboratif memerlukan sejumlah praktik kelompok ideal (Skinner, Braunack-Mayer, \& Winning, 2016, p. 2).

Proses pembelajaran berbasis masalah dalam penelitian terdiri dari lima pokok tahapan yang dimulai dengan menentukan masalah yang dihadapkan pada peserta didik sampai dengan melakukan refleksi pembelajaran. Adapun langkah-langkah dalam pelaksanaan model pembelajaran berbasis masalah ini seperti di bawah ini:
1. Pendidik menjelaskan tujuan pembelajaran, menjelaskan alat bahan yang dibutuhkan, mengajukan fenomena atau demonstrasi atau cerita untuk memunculkan masalah, memotivasi siswa untuk terlibat dalam pemecahan masalah yang dipilih;

2. Pendidik membantu peserta didik mendefinisikan dan mengorganisasi tugas belajar yang berhubungan dengan masalah tersebut;

3. Pendidik mendorong peserta didik dalam mengumpulkan informasi yang diperlukan, melaksanakan eksperimen untuk mendapatkan penjelasan dan pemecahan masalah;

4. Pendidik membantu peserta didik dalam merencanakan dan mempersiapkan karya yang sesuai seperti, laporan, video, dan model serta mambantu mereka untuk berbagai tugas dengan temannya;

5. Pendidik membantu peserta didik untuk melakukan merefleksi hasil atau mengevaluasi penyelidikan mereka dan proses-proses yang mereka gunakan (Sumantri, 2015, pp. 47-48).

Berdasarkan pernyataan-pernyataan di atas, maka mendorong penulis untuk mengadakan penelitian tentang "pengaruh model pembelajaran berbasis masalah terhadap motivasi belajar dan hasil belajar dalam pembelajaran PPKn pada pokok materi Napak Tilas Penegakan Hak Asasi Manusia di SMA Negeri 1 Pacet Kabupaten Mojokerto.

\section{Metode}

Penelitian ini dilaksanakan di SMA Negeri 1 Pacet Kabupaten Mojokerto pada kelas X. SMA Negeri 1 Pacet Kabupaten Mojokerto beralamat di Jl. Pandanarum, Kecamatan Pacet, Kabupaten Mojokerto. Populasi dalam penelitian ini adalah peserta didik kelas X SMA Negeri 1 Pacet Kabupaten 
Mojokerto tahun ajaran 2016/2017. Kelas X di SMA Negeri 1 Pacet Kabupaten Mojokerto terdiri dari 9 kelas. Pemilihan sampel untuk kelompok kontrol dan eksperimen dilakukan dengan teknik simple random sampling. Berdasarkan pemilihan sampel, diperoleh kelas X IIS-4, sebagai kelompok kontrol, kelas X MIA-1 sebagai kelompok eksperimen 1, dan kelas X MIA-5 sebagai kelompok eksperimen 2.

Rancangan penelitian yang digunakan adalah eksperimen semu (quasi-experiment) dengan pretest-posttest control group design. Prosedur penelitian adalah: (1) menetapkan rumusan masalah; (2) menentukan populasi; (3) menetapkan sampel dengan teknik simple random sampling (satu kelompok kontrol dan dua kelompok eksperimen); (4) membuat instrumen penelitian. Instrumen tes untuk mengukur hasil belajar ranah kognitif. Instrumen angket untuk mengukur motivasi belajar; (5) melakukan uji validitas isi; (6) melakukan uji coba instrumen pada kelas XI; (7) melakukan uji validitas butir soal dan angket; (8) melakukan pretest untuk soal dan angket pada kelompok kontrol, kelompok eksperimen 1, dan kelompok eksperimen 2; (9) melaksanakan proses pembelajaran di kelas X.

Kelompok kontrol dengan metode konvensional, kelompok eksperimen 1 dengan model pembelajaran berbasis masalah, dan kelompok eksperimen 2 dengan model pembelajaran inquiry; (8) melakukan posttest untuk soal dan angket pada kelompok kontrol, kelompok eksperimen 1, dan kelompok eksperimen 2. Data yang diperoleh merupakan data hasil belajar dan motivasi belajar. Data yang telah diperoleh dianalisis menggunakan SPSS 21.0 for Windows.

Data terdiri dari hasil belajar ranah kognitif dan motivasi belajar. Teknik pengumpulan data menggunakan teknik tes dan angket. Tes ini dilakukan sebanyak dua kali, yaitu pretest dan posttest. Angket diberikan sebanyak dua kali, yaitu sebelum peserta didik dikenai perlakuan dan setelah dikenai perlakuan. Instrumen pengumpulan data menggunakan tes dan angket. Instrumen tes digunakan untuk mengukur hasil belajar peserta didik ranah kognitif berupa tes tulis yang disusun dalam bentuk test objektif. Instrumen tes terdiri dari 20 butir pertanyaan. Sementara itu angket digunakan untuk mengukur motivasi belajar peserta didik. Instrumen angket dalam penelitian ini terdiri dari 16 butir pernyataan.

Teknik analisis data menggunakan rumus statistik, yakni independent-sample t-test. Semua data yang telah diperoleh di awal maupun akhir pertemuan sebelum dianalisis dengan uji hipotesis, terlebih dahulu dilakukan uji prasyarat analisis yang meliputi uji normalitas dan uji homogenitas varian. Data yang akan diuji adalah data pretest, posttest, penilaian diri awal dan akhir. Sementara itu data yang diuji dengan independent-sample t-test adalah data posttest, baik pada kelompok kontrol, kelompok eksperimen 1, dan kelompok eksperimen 2. Pengujian tersebut dilakukan untuk menganalisis perbedaan hasil belajar dan motivasi belajar antara kelompok kontrol, kelompok eksperimen 1, dan kelompok eksperimen 2. Jika hasil uji beda tersebut menunjukkan perbedaan yang signifikan maka dapat diketahui bahwa model pembelajaran berbasis masalah memberikan pengaruh terhadap motivasi belajar dan hasil belajar peserta didik. Selain itu, pengujian dilakukan untuk mengetahui efektivitas antara model pembelajaran berbasis masalah, model inquiry, dan model konvensional dengan menggunakan gain score. 


\section{Hasil dan Pembahasan}

Hasil penelitian dianalisis untuk menjawab hipotesis yang telah dibuat. Hipotesis tersebut dapat dijawab dengan melakukan uji anava dan manova pada hasil posttest untuk variabel motivasi belajar dan hasil belajar peserta didik antara kelompok kontrol dan kelompok eksperimen dalam pembelajaran Pendidikan Kewarganegaraan pada pokok materi Napak Tilas Penegakan Hak Asasi Manusia.

Hipotesis pertama yang terdapat dalam penelitian ini adalah "Terdapat pengaruh positif dan signifikan model pembelajaran berbasis masalah terhadap hasil belajar peserta didik di SMA Negeri 1 Pacet

Tabel 1 Hasil uji Anava Motivasi Belajar Peserta didik Kelas Eksperimen 1, eksperimen 2, dan Kelas Kontrol

\begin{tabular}{|c|c|c|c|c|}
\hline Data & Mean & Sig & F hitung & Ket. \\
\hline Eksperimen 1 & 61,15 & 0,000 & 10,933 & Signifikan \\
\hline Eksperimen 2 & 56,06 & & & $\begin{array}{c}(\mathrm{P}:=0,000 \\
<0,05)\end{array}$ \\
\hline Kelas Kontrol & 52,61 & & & \\
\hline
\end{tabular}

Sumber: data hasil penelitian, 2017.

Hasil penelitian ini menguatkan penelitian terdahulu yang dilakukan oleh Kustyorini (2012), yang menyimpulkan bahwa model pembelajaran berbasis masalah dan berpengaruh signifikan terhadap aktivitas peserta didik. Aktivitas peserta didik menunjukkan bahwa motivasi peserta didik setelah menggunakan berbasis masalah menjadi lebih baik dibandingkan pembelajaran konvensional. Penelitian ini juga sesuai dengan penelitian yang dilakukan oleh Fadly (2012), menyimpulkan bahwa aktivitas peserta didik setelah menggunakan model pembelajaran Problem Based Learning $(P B L)$ mengalami peningkatan. Model pembelajaran Problem Based Learning (PBL) mendorong motivasi belajar peserta didik
Kabupaten Mojokerto. Berdasarkan hasil analisis menggunakan uji anava dapat diketahui besar $\mathrm{F}$ hitung adalah 10,933 dan nilai $\mathrm{F}$ tabel dengan $\mathrm{db}$ 2:95 pada taraf signifikansi 5\% sebesar 3,09 atau Nilai p lebih kecil dari 0,05. Nilai tersebut menunjukkan bahwa terdapat perbedaan motivasi belajar antara peserta didik yang menggunakan model pembelajaran berbasis masalah (eksperimen 1), model pembelajaran inquiry (eksperimen 2) dan model pembelajaran konvensional (kelas kontrol). Berdasarkan hasil uji anava motivasi belajar peserta didik kelas eksperimen 1, eksperimen 2, dan kelas kontrol dapat ditunjukkan pada tabel 1 . 
dapat memecahkan masalah dalam situasi interdisipliner dan nyata.

Pendapat di atas diperkuat oleh pendapat (Echavarria, 2010, p. 86), bahwa pembelajaran berbasis masalah adalah strategi pedagogis yang berpusat pada peserta didik dengan mengkaji masalah-masalah dalam kehidupan sehari-hari dan bekerja dalam tim atau kelompok, dengan demikian dapat melatih peserta didik untuk bertanggung jawab dalam pembelajaran mereka sendiri dan mengubah peran pendidik menjadi fasilitator. Hal ini juga sama dengan pendapat Wlodkowski \& Jaynes (dalam Novianti, 2011, p. 161), bahwa motivasi belajar merupakan suatu proses internal yang ada dalam diri seseorang yang memberikan gairah atau semangat dalam belajar, mengandung usaha untuk mencapai tujuan belajar, dimana terdapat pemahaman dan pengembangan belajar. Hal senada juga dikemukakan Glynn, Aultman, \& Owens (2005, p. 150), bahwa "motivation is an internal state that arouses, directs, and sustains human behavior.

Adanya perbedaan hasil belajar peserta didik pada kelas eksperimen 1, eksperimen 2 dan kelas kontrol tidak terlepas dari adanya proses pembelajaran yang dilalui peserta didik. Dalam proses pembelajaran berbasis masalah peserta didik diarahkan untuk menyelesaikan permasalahan-permasalahan yang sedang dibahas melalui serangkaian pembelajaran yang sistematis. Peserta didik dituntut untuk mencari data dan informasi yang dibutuhkan dari berbagai sumber

\begin{tabular}{ccccc}
\hline Data & Mean & Sig & F hitung & Ket. \\
\hline Eksperimen 1 & 6,88 & 0,000 & 32,737 & Signifikan \\
Eksperimen 2 & 5,85 & & & $(\mathrm{P}:=0,000$ \\
Kelas Kontrol & 4,81 & & & $<0,05)$ \\
\hline
\end{tabular}

Sumber: data diolah peneliti, 2017.

\section{Tabel 2 Hasil Uji Anava Hasil Belajar Eksperimen 1, 2, dan Kelas Kontrol}

dengan tujuan untuk menganalisa permasalahan-permasalahan yang dihadapi. Hal ini menimbulkan motivasi dalam diri siswa untuk dapat menyelesaikan permasalahan dalam pembelajaran. Hal ini didukung pendapat dari (2016, p. 120) bahwa kelebihan pembelajaran dengan model PBL adalah dapat mendorong siswa untuk bekerja sama dalam kelompok.

Pendapat di atas juga diperkuat dengan pendapat Sumantri (2015, pp. 46-47) kelebihan pembelajaran berbasis masalah antara lain: (a) melatih siswa untuk mendesain suatu penemuan; (b) berpikir dan bertindak kreatif; (c) siswa dapat memecahkan masalah yang dihadapi secara realistis; (d) mengidentifikasi dan mengevaluasi penyelidikan; (e) menafsirkan dan mengevaluasi hasil pengamatan; (f) merangsang bagi perkembangan kemajuan berpikir siswa untuk menyelesaikan suatu permasalahan yang dihadapi dengan tepat; (g) dapat membuat pendidikan lebih relevan dengan kehidupan.

Hipotesis kedua dalam penelitian ini adalah "Terdapat pengaruh positif dan signifikan model pembelajaran berbasis masalah terhadap hasil belajar peserta didik di SMA Negeri 1 Pacet Kabupaten Mojokerto". Analisis yang digunakan dalam penelitian ini adalah analisis varians. Nilai signifikan apabila $p$ lebih kecil dari 0,05. Berdasarkan hasil uji hasil belajar peserta didik kelas eksperimen 1, eksperimen 2, dan kelas kontrol ditunjukkan pada tabel 2. 
Tabel di atas diketahui besar $\mathrm{F}$ hitung adalah 32,737 dan nilai $\mathrm{F}$ tabel dengan $\mathrm{db}$ 2:95 pada taraf signifikansi 5\% sebesar 3,09. Nilai F hitung > F tabel atau Nilai p lebih kecil dari 0,05. Nilai tersebut menunjukkan bahwa terdapat perbedaan hasil belajar antara peserta didik yang menggunakan model pembelajaran berbasis masalah (eksperimen 1), model pembelajaran inquiry (eksperimen 2) dan model pembelajaran konvensional (kelas kontrol). Hal ini berarti ada pengaruh model pembelajaran berbasis masalah terhadap hasil belajar peserta didik di SMA Negeri 1 Pacet Kabupaten Mojokerto.

Hasil penelitian ini menguatkan penelitian terdahulu yang dilakukan oleh Fadly (2012). Hasil penelitian tersebut juga menyimpulkan bahwa hasil belajar peserta didik setelah menggunakan model pembelajaran Problem Based Learning (PBL) mengalami peningkatan. Penelitian ini juga dikuatkan dengan pendapat yang dikemukakan oleh (Hmelo-Silver, 2004, p. 236), menyatakan bahwa melalui kegiatan pembelajaran berbasis masalah peserta didik diajak dapat membentuk kelompokkelompok untuk melakukan investigasi dalam pemecahan masalah dalam satu kelompok, sedangkan peran pendidik adalah sebagai fasilitator untuk membantu jalannya diskusi serta membantu untuk mengarahkan mencari berbagai informasi atau sumber sebagai bahan peserta didik untuk mencari solusi sampai dapat menarik kesimpulan sebelum dipaparkan hasil kelompok tersebut. Melalui model pembelajaran berbasis masalah peserta didik dapat mengembangkan pengetahuan yang telah dimilikinya agar memperoleh hasil yang maksimal.

Adanya perbedaan hasil belajar peserta didik pada kelas eksperimen 1, eksperimen 2, dan kelas kontrol tidak terlepas dari adanya proses pembelajaran yang dilalui peserta didik. Dalam proses pembelajaran berbasis masalah meliputi tahapan memberikan orientasi tentang permasalahannya kepada peserta didik, mengorganisasikan peserta didik untuk belajar, membimbing penyelidikan mandiri atau kelompok, mengembangkan dan mempresentasikan informasi atau hasil, menganalisis dan mengevaluasi proses pemecahan masalah. Hal tersebut serupa dengan pendapat Forsythe (2002), bahwa langkah-langkah dari model pembelajaran berbasis masalah meliputi "the problem/task, first meeting, research, feedback session, and group's response".

Langkah yang terdapat dalam model pembelajaran berbasis masalah membantu peserta didik untuk menganalisis sumber informasi yang didapatkan dari lingkungan sekelilingnya, selanjutnya membangun kembali berpikir kritis pada peserta didik, sehingga pemahaman peserta didik menjadi lebih baik yang pada akhirnya berdampak pada hasil belajar peserta didik. Hal ini juga dikuatkan dengan pendapat Schettino (Schettino, 2016), menyatakan bahwa melalui pembelajaran berbasis masalah di dalam kelas adalah tempat untuk merangsang kemampuan berkomunikasi, keterampilan metakognitif, keterampilan belajar seumur hidup, dan pengetahuan konten dipraktikkan dengan berfokus pada masalah. Berpikir adalah aktivitas kognitif tingkat tinggi yang melibatkan asimilasi dan akomodasi berbagai pengetahuan dan struktur kognitif yang dimiliki peserta didik untuk memecahkan suatu masalah, sehingga hasil belajar peserta didik menjadi lebih optimal.

Berbagai faktor yang dapat mempengaruhi hasil belajar peserta didik saat 
mengikuti kegiatan belajar mengajar, termasuk motivasi belajar peserta didik yang rendah, model yang digunakan kurang menarik, sehingga peserta didik cepat bosan, dan pembelajaran kurang melibatkan peserta didik dalam kegiatan-kegiatan yang secara langsung atau kolaboratif dengan teman yang lainnya. Hal ini diperkuat pendapat dari Cindy \& Silver (Hmelo-Silver, 2004, p. 236), model PBL, siswa bekerja dalam kelompok kolaboratif kecil dan mempelajari apa yang mereka perlu tahu untuk memecahkan masalah yang dihadapi, misalnya di lingkungan sekitar atau masalah-masalah yang ada dalam kehidupan sehari-hari. Guru bertindak sebagai fasilitator untuk membimbing siswa belajar melalui siklus belajar.

Hipotesis ketiga dalam penelitian ini adalah "Terdapat pengaruh positif dan signifikan model pembelajaran berbasis masalah terhadap motivasi belajar dan hasil belajar peserta didik di SMA Negeri 1 Pacet Kabupaten Mojokerto". Analisis pada hipotesis ketiga dalam penelitian ini menggunakan uji manova. Hasil uji manova dalam penelitian ini dapat ditunjukkan pada tabel 3 dibawah ini.

Tabel 3 Hasil Analisis Uji Manova

\begin{tabular}{cc}
\hline Efek & Signifikan \\
\hline Hotelling's Trance & 0,000 \\
\hline
\end{tabular}

Sumber: data hasil penelitian, 2017.

Berdasarkan hasil uji manova di atas diketahui nilai signifikansi lebih kecil dari $0,05(\mathrm{p}=0,000<0,05)$. Nilai tersebut menunjukkan bahwa terdapat pengaruh positif dan signifikan model pembelajaran berbasis masalah terhadap motivasi belajar dan hasil belajar peserta didik di SMA Negeri 1 Pacet Kabupaten Mojokerto, sehingga hipotesis diterima.
Hasil penelitian ini menguatkan penelitian yang dilakukan Kustyorini (2012), menyimpulkan bahwa model pembelajaran berbasis masalah berpengaruh signifikan terhadap aktivitas belajar dan hasil belajar peserta didik. Hasil penelitian di atas didukung pendapat dari diperoleh Ames, 1990; Dweck, 1986 (dalam Liu, 2005) motivasi pembelajaran di kelas telah menunjukkan bahwa motivasi memainkan peran penting dalam mempengaruhi kegiatan belajar dan prestasi yang diperoleh. Hal senada dengan pendapat Tan, Teo, \& Chye (2009, p. 5), bahwa "program pendidikan dengan orientasi kreatif pemecahan masalah untuk merangsang proses kreatif peserta didik, serta dapat meningkatkan berpikir kreatif peserta didik dengan laporan-laporan yang diterima".

Berbagai faktor yang dapat mempengaruhi motivasi belajar peserta didik yang dapat berdampak pada hasil belajar yang diperoleh kurang maksimal. Seperti yang diungkapkan oleh Susanti \& Andriani (2013, pp. 3-4), motivasi belajar merupakan salah satu karakteristik yang dapat mempengaruhi aspek afektif. Peserta didik yang memiliki motivasi belajar akan memperhatikan dan berusaha untuk mengingat apa yang telah diajarkan oleh guru, karena semua itu untuk mencapai cita-citanya. Motivasi belajar tidak hanya dipengaruhi oleh faktor intern dari diri siswa saja, tetapi juga dipengaruhi oleh faktor eksternal yaitu dari lingkungan keluarga, lingkungan masyarakat, dan lingkungan sekolah.

Berdasarkan hasil penelitian di atas didukung oleh pendapat Segura et al (2012, p. 15), bahwa salah satu faktor kunci keberhasilan meningkatkan motivasi siswa ialah: 
1. Hubungkan dengan kepentingan pribadi siswa. Biarkan mereka memberikan umpan balik dari sudut pandang mereka sendiri dan menghargai aspek pribadi;

2. Buatlah relevan untuk mereka. Menghubungkan konten untuk situasi saat ini. Gunakan contoh-contoh dari dunia mereka hidup;

3. Memberikan perhatian yang positif dan konfirmasi, dan;

4. Perkenalkan kemungkinan untuk memilih. Hasilnya kepemilikan menciptakan motivasi intrinsic peserta didik.

Hipotesis keempat dalam penelitian ini adalah "terdapat model yang paling efektif antara model pembelajaran berbasis masalah, model pembelajaran inquiry, dan model pembelajaran konvensional dalam pembelajaran PPKn". Analisis yang digunakan dalam menentukan model yang paling efektif dalam pembelajaran PPKn di SMA Negeri 1 Pacet Kabupaten Mojokerto ialah uji gain score dari ketiga model pembelajaran tersebut juga dapat dilihat dari perolehan gain score motivasi belajar ialah sebagai berikut.

Tabel 4. Hasil Gain Score Motivasi Belajar

\begin{tabular}{ccc}
\hline Kelas & Gain Score & Kategori \\
\hline Eksperimen 1 & 0.35 & Sedang \\
Eksperimen 2 & 0.16 & Rendah \\
Kelas Kontrol & 0.03 & Rendah \\
\hline
\end{tabular}

Sumber: data diolah peneliti, 2017.

Berdasarkan hasil analisis menggunakan gain score menunjukkan bahwa peserta didik yang menggunakan model pembelajaran berbasis masalah memperoleh gain score sebesar 0,35 dalam kategori sedang. Peserta didik yang menggunakan model pembelajaran inquiry memperoleh gain score sebesar 0,16 dalam kategori rendah dan perolehan gain score pada kelas kontrol yang menggunakan model pembelajaran konvensional sebesar 0,03 dalam kategori rendah. Selanjutnya untuk mengetahui keefektifan dari tiga model pembelajaran yang telah digunakan dalam penelitian ini dilihat dari hasil belajar peserta didik dapat dilihat dari perolehan gain score hasil belajar peserta didik ialah sebagai berikut.

Tabel 5. Hasil Gain Score Hasil Belajar

\begin{tabular}{ccc}
\hline Kelas & Gain Score & Kategori \\
\hline Eksperimen 1 & 0.37 & Sedang \\
Eksperimen 2 & 0.19 & Rendah \\
Kelas Kontrol & 0.04 & Rendah \\
\hline
\end{tabular}

Sumber: data diolah peneliti, 2017.

Berdasarkan hasil analisis menggunakan gain score menunjukkan bahwa peserta didik yang menggunakan model pembelajaran berbasis masalah memperoleh gain score sebesar 0,37 dalam kategori sedang. Peserta didik yang menggunakan model pembelajaran inquiry memperoleh gain score sebesar 0,19 dalam kategori rendah dan perolehan gain score pada kelas kontrol yang menggunakan model pembelajaran konvensional sebesar 0,04 dalam kategori rendah.

Pembelajaran berbasis masalah merupakan strategi pedagogis yang berpusat pada peserta didik dengan mengkaji masalahmasalah dalam kehidupan sehari-hari dan bekerja dalam tim atau kelompok, dengan demikian dapat melatih peserta didik untuk bertanggung jawab dalam pembelajaran mereka sendiri dan mengubah peran pendidik menjadi fasilitator. Hal ini senada dengan pendapat (2015, pp. 37-38) bahwa "dalam membantu siswa untuk mengembangkan proses pembelajaran PBL guru harus 
menentukan kedalaman pengetahuan siswa, desain sesuai pengalaman belajar bagi kelompok siswa, membantu siswa dalam belajar dan berlatih pengetahuan dan keterampilan baru, mengevaluasi belajar siswa, dan memberikan para siswa dengan umpan balik yang akan mendorong pembelajaran lebih lanjut".

Berdasarkan hasil penelitian di atas didukung pendapat dari Armigate, Pihl, \& Ryberg (2015, p. 1) bahwa "pembelajaran berbasis masalah merupakan pendekatan pedagogis yang mendorong orang-orang yang mengambil bagian dalam proses untuk bertindak baik agen perubahan sebagai mendukung bekerja sama dengan rekanrekan, dan juga sebagai individu untuk menggunakan kreativitas mereka dalam menemukan solusi untuk masalah-masalah praktis".

Melalui kegiatan pembelajaran berbasis masalah peserta didik diajak membentuk kelompok-kelompok untuk melakukan investigasi dalam pemecahan masalah dalam satu kelompok, sedangkan peran pendidik adalah sebagai fasilitator untuk membantu jalannya diskusi serta membantu untuk mengarahkan mencari berbagai informasi atau sumber sebagai bahan peserta didik untuk mencari solusi sampai dapat menarik kesimpulan atas permasalahan-permasalahan yang telah dibahas. Dengan demikian kegiatan pembelajaran lebih bermakna dan materi yang disampaikan oleh pendidik lebih mudah diterima.

\section{Simpulan}

Berdasarkan hasil penelitian dan pembahasan yang telah diuraikan, dapat ditarik kesimpulan sebagai berikut.

1. Terdapat pengaruh positif dan signifikan model pembelajaran berbasis masalah terhadap motivasi belajar peserta didik di
SMA Negeri 1 Pacet Kabupaten Mojokerto. Hal ini ditunjukkan dari nilai F hitung > F tabel $(10,933>3,09)$ atau nilai $\mathrm{p}$ lebih kecil dari $0,05(\mathrm{p}=0,000<$ $0,05)$.

2. Terdapat pengaruh positif dan signifikan model pembelajaran berbasis masalah terhadap hasil belajar peserta didik di SMA Negeri 1 Pacet Kabupaten Mojokerto. Hal ini ditunjukkan dari nilai F hitung > F tabel $(32,737>3,09$ atau nilai $\mathrm{p}$ lebih kecil dari $0,05(\mathrm{p}=0,000<$ $0,05)$.

3. Terdapat pengaruh positif dan signifikan model pembelajaran berbasis masalah terhadap motivasi belajar dan hasil belajar peserta didik di SMA Negeri 1 Pacet Kabupaten Mojokerto. Hal ini ditunjukkan dari nilai signifikansi lebih kecil dari 0,05 $(\mathrm{p}=0,000<0,05)$.

4. Model yang paling efektif dalam pembelajaran ppkn di SMA Negeri 1 Pacet yaitu model pembelajaran berbasis masalah. Hal ini ditunjukkan hasil skor gain scor motivasi belajar siswa sebesar 0,35 dan didukung hasil gain scor pada hasil belajar peserta didik sebesar 0,37. Artinya model pembelajaran berbasis masalah termasuk model yang paling efektif dalam pembelajaran ppkn dibandingkan model yang lain.

Berdasarkan hasil penelitian, pembahasan, dan kesimpulan maka implikasi dalam penelitian ini ialah sebagai berikut.

1. Model pembelajaran berbasis masalah berpengaruh terhadap hasil belajar dan motivasi belajar peserta didik. Model pembelajaran secara efektif dapat mengembangkan kemampuan berpikir peserta didik dengan memecahkan masalah yang dapat berdampak pada aktivitas kognitif tingkat tinggi pada 
peserta didik, sehingga hasil belajar menjadi lebih optimal. Melalui model pembelajaran berbasis masalah proses pembelajaran yang dilalui peserta didik menjadi lebih menyenangkan dan lebih disukai peserta didik, sehingga mendorong motivasi belajar;

2. Penerapan model pembelajaran berbasis masalah tidak dapat diterapkan di keseluluhan materi yang terdapat di kurikulum satuan pendidikan. Sehingga perlu menyesuaikan antara model yang digunakan dengan pokok materi yang akan disampaikan.

Materi pokok yang sesuai dengan model pembelajaran berbasis masalah ialah materi yang berkaitan dengan analisis kasus dan materi yang memuat isu-isu kontroversial. Adapun kompetensi dasar yang sesuai dengan penggunaan model pembelajaran berbasis masalah ialah sebagai berikut. (a) mata pelajaran Pendidikan Pancasila dan Kewarganegaraan (PPKn), SMA pada Kelas X mencakup; 1) Kompetensi Dasar 3.1 dengan pokok bahasan menganalisis kasus-kasus pelanggaran HAM dalam rangka pelindungan dan pemajuan HAM sesuai dengan nilai-nilai Pancasila dalam kehidupan bermasyarakat, berbangsa, dan bernegara; 2). Kompetensi Dasar 3.4 dengan pokok memahami hubungan struktural dan fungsional pemerintahan pusat dan daerah menurut Undang-Undang Dasar Negara Republik Indonesia Tahun 1945).

Kompetensi Dasar 3.5 dengan pokok bahasan memahami sistem hukum dan peradilan nasional dalam lingkup NKRI; 4). Kompetensi Dasar 3.6 dengan pokok bahasan menganalisis kasus pelanggaran hak dan pengingkaran kewajiban sebagai warga negara; dan 5). Kompetensi Dasar 3.7 dengan pokok bahasan menganalisis indikator ancaman terhadap negara dalam membangun integrasi nasional dengan bingkai Bhinneka Tunggal Ika. (b) mata pelajaran Pendidikan Pancasila dan Kewarganegaraan (PPKn), SMA pada Kelas XI mencakup: 1). Kompetensi Dasar 3.1 dengan pokok bahasan menganalisis kasus pelanggaran HAM dalam rangka pelindungan, pemajuan, dan pemenuhan HAM; 2). Kompetensi Dasar 3.2 dengan pokok bahasan menganalisis pasal-pasal yang mengatur tentang wilayah Negara, warga Negara dan penduduk, agama dan kepercayaan, pertahanan dan keamanan; 3). Kompetensi Dasar 3.3 dengan pokok bahasan menganalisis perkembangan demokrasi dalam kehidupan bermasyarakat, berbangsa dan bernegara; 4). Kompetensi Dasar 3.5 dengan pokok bahasan menganalisis praktik perlindungan dan penegakan hukum dalam masyarakat untuk menjamin keadilan dan kedamaian; dan 5). Kompetensi Dasar 3.6 dengan pokok bahasan menganalisis kasus pelanggaran hak dan pengingkaran kewajiban sebagai warga Negara.

Beberapa saran yang dapat disampaikan sebagai berikut:

1. guru diharapkan mampu untuk melanjutkan penggunaan model pembelajaran berbasis masalah dalam pembelajaran PPKn sehingga hasil belajar dan motivasi belajar pada peserta didik akan terus meningkat

2. peneliti lainnya diharapkan dapat memanfaatkan penelitian ini sebagai bahan acuan dalam melaksanakan penelitian berikutnya dan dapat memaksimalkan upaya penerapan model pembelajaran berbasis masalah disertai media, sehingga hasil belajar dan motivasi 
belajar peserta didik menjadi lebih optimal; dan

3. sebelum diterapkannya model pembelajaran berbasis masalah diperlukan terlebih dahulu memilih atau menentukan pokok pembahasan yang sesuai dengan langkah-langkah dalam model pembelajaran, hal ini diharapkan dapat membantu peserta didik mencapai kompetensi.

\section{Daftar Pustaka}

Andartari, Susanti, S., \& Andriani, V. (2013). Pengaruh kemampuan intelektual (IQ) dan motivasi belajar terhadap hasil belajar siswa pada mata pelajaran akuntansi pada SMA Labschool Rawamangun. Jurnal Pendidikan Ekonomi Dan Bisnis, 1(1), 124.

Armitage, A., Pihl, O., \& Ryberg, T. (2015). PBL and creative processes. Journal of Problem Based Learning in Higher Education, 3(1), 1-4. http://doi.org/10.5278/ojs.jpblhe.v3i1.11 99

Chen, W.-H. (2013). Applying problembased learning model and creative design to conic-sections teaching. International Journal of Education and Information Technologies, 3(7), 73-80.

Echavarria, M. V. (2010). Problem-based learning application in engineering. Revista EIA. scieloco.

Etherington, M. B. (2011). Investigative primary science: A problem-based learning approach. Australian Journal of Teacher Education (Online), 36(9), 5374.

Fadly, A. (2012). Peningkatan aktivitas dan hasil belajar siswa melalui model pembelajaran problem based learning (PBL) (Studi pada kelas $\mathrm{x}$ bisnis dan manajemen mata pelajaran kewirausahaan di SMK Mrdjuna 1 Malang). Jurnal Fakultas Ekonomi Universitas Negri Malang, 1-15.
Glynn, S. M., Aultman, L. P., \& Owens, A. M. (2005). Motivation to learn in general education programs. The Journal of General Education, 54(2), 150-170.

Hmelo-Silver, C. E. (2004). Problem-based learning: What and how do students learn? Educational Psychology Review, 16(3), 235-267.

Kustyorini, Y. (2012). Pengaruh pembelajaran berbasis masalah dilengkapi media virtual terhadap aktivitas dan hasil belajar fisika SMA/MA. Tesis pada Program Pascasarjana Universitas Negeri Yogyakarta.

Liu, M. (2005). Motivating students through problem-based learning. In Annual National Educational Computing Conference (NECC) Philadelphia, PA, June.

Novianti, N. R. (2011). Kontribusi pengelolaan laboratorium dan motivasi belajar siswa terhadap efektifitas proses pembelajaran (Penelitian pada SMP negeri dan swasta di Kabupaten Kuningan Provinsi Jawa Barat). Jurnal UPI, Edisi Khus(1).

Salani, E., \& Maphane, E. P. (2014). Botswana primary school teachers' motivational strategies beliefs about mathematics classroom instructional practices. International Journal of Humanities Social Sciences and Education (IJHSSE), 1(11), 217-227.

Schettino, C. (2016). A Framework for Problem-Based Learning: Teaching Mathematics with a Relational ProblemBased Pedagogy. Interdisciplinary Journal of Problem-Based Learning, 10(2), 42-67. http://doi.org/10.7771/1541-5015.1602

Segura, O. C., Deledicque, J.-P., Hogh, P., Marques, C., Beelprez, L., Solís, J. C., ... Frank Van Wolvelaer. (2012). Quality Development At School In-Company Classes Motivating Teaching And Learning Methods. TL+Q. Retrieved from www.tlqproject.eu\%0AThis 
Skinner, V. J., Braunack-Mayer, A., \& Winning, T. A. (2016). Another Piece of the "Silence in PBL" Puzzle: Students' Explanations of Dominance and Quietness as Complementary Group Roles. Interdisciplinary Journal of Problem-Based Learning, 10(2), 12-25. http://doi.org/10.7771/1541-5015.1607

Sumantri, M. S. (2015). Strategi pembelajaran: Teori dan praktik di tingkat pendidikan dasar. Jakarta: PT. Raja Grafindo Persada.

Tan, O., Teo, C.-T., \& Chye, S. (2009). Problem and creativity. In O.-S. Tan (Ed.), Program-Based Learning ad creativity (pp. 1-14). Singapore: Cengage Learning Asia Pte Ltd.

Walters, L. M. (2015). Perceptions of the effects of a constructivist classroom approach on academic service- learning: An exploratory study. The BRC Academy Journal of Business, 5(1), 35-65. http://doi.org/dx.doi.org/10.15239/j.brcac adjb.2015.04.01.ja03

Wijayanti, A., \& Wulandari, T. (2016). Efektivitas model CTL dan model PBL terhadap hasil belajar IPS. Harmoni Sosial: Jurnal Pendidikan IPS, 3(2), 112124. 